\title{
ANA ÁlVAREZ-ERRECALDE. UN EJEMPLO DE LO QUE ACONTECE EN LA CONFLUENCIA DE LA MATERNIDAD Y LA CREACIÓN PLÁSTICA'
}

\author{
ANA ÁLVAREZ-ERRECALDE. AN EXAMPLE OF DEVELOPMENTS
}

IN THE CONVERGENCE OF MATERNITY AND VISUAL CREATION

\author{
Ana $M^{a}$ Palomo-Chinarro \\ Universidad de Vic-Universidad Central de Cataluña (Barcelona)
}

\section{RESUMEN}

La artista argentina Ana Álvarez-Errecalde reúne en su condición de artista y mujer dos elementos destacables: la visibilidad y la transgresión.

Como artista visual aporta la construcción de referentes, identitarios y de género, al imaginario de una sociedad que los precisa. Situada en la periferia del poder, Ana Álvarez-Errecalde escarba en su medio interno y en el exterior para encontrar un marco propio que invite a la transgresión, una transgresión que implica el ensayo de alternativas y propuestas conceptualizadas para la realización de su obra. El relato nos la presentará de forma indirecta, a través de un texto no lineal sino fragmentario, pues nos consta que en el trabajo de la artista no hay nada definitivo, al contrario, su labor creativa, igual que la personal, se va construyendo con el paso del tiempo y en absoluta libertad.

Palabras clave: Arte, maternidad, estudios feministas, estudios género.

\section{ABSTRACT}

The Argentinean artist Ana Álvarez-Errecalde uses her condition of artist and woman to combine two notable features: visibility and transgression.

As a visual artist she contributes the construction of references, identity and gender to the imaginary of a society that needs them. Situated on the margins of power, Ana Álvarez-Errecalde digs inside and outside herself to find her own framework which invites transgression: transgression which implies the testing of alternatives and conceptualized proposals in order to carry out her work. Her story will be

1 Este texto se inscribe en las actividades del Grupo de Estudios de Género: Traducción, Literatura, Historia y Comunicación (GETLIHC) (2014 SGR 62). Universidad de Vic-Universidad Central de Cataluña (Barcelona).

Número ORCID de la investigadora: 0000-0002-1887-027X. 
told indirectly, through a fragmented rather than non-linear text, since we know that in the artist's work there is nothing definite: on the contrary, her creative labour, like her personal work, is built over time and in total liberty.

Keywords: Art, maternity, feminist studies, gender studies.

\section{Exordio}

La artista argentina Ana Álvarez-Errecalde reúne, en su condición de artista y mujer, dos elementos imprescindibles para formar parte del elenco de personajes que se dan cita en uno de los ejes temáticos, biografías y retratos de género, sobre los que se organiza este congreso: la visibilidad y la transgresión.

Como artista visual aporta la construcción de referentes, identitarios y de género, al imaginario de una sociedad, la actual, que los precisa y que los demanda. Las imágenes se constituyen por sí mismas en mecanismos inmediatos y directos para transmitir emociones, y esta inmediatez y agilidad en la transmisión de ideas o conceptos las antepone a la palabra. Abundando en ello sólo cabe hacernos eco del pensamiento de Antoni Gutiérrez-Rubí cuando propone: «pensar en imágenes, recuperar la expresión artística y de las artes visuales para la comunicación del pensamiento social y político. Imaginar las ideas, imaginando sus iconos y símbolos. Conectar los sueños y las propuestas con su visión, con su representación. Imágenes para cambiar el mundo» (Gutiérrez-Rubí, 2009: s.p.). Si a ello le añadimos la posibilidad de utilizar toda la multiplicidad de plataformas de amplificación y de distribución que encuentran estas imágenes a través de los mass media y de las redes sociales, podremos convenir en que esta visibilidad constituye un elemento sustancial para desafiar al sistema, sobre todo cuando va, íntima e indisolublemente, unida a la transgresión.

A su vez, atendiendo a lo que Marcela Lagarde (2000) sugería en su ensayo Ética y política alternativa, la transgresión se opone al orden dominante y las mujeres que se alinean en esta condición abandonan las filas del gregarismo y del orden para adoptar otro paradigma, otra propuesta y otras alternativas diferentes. Esta idea de la transgresión se identifica plenamente con el ideario de esta artista, una mujer que no ha dudado nunca en mostrar su rebeldía y que se ha desmarcado de manera continuada del orden establecido. Ana Álvarez-Errecalde forma parte del grupo de personas que no encuentran fácil acomodo en la sociedad que se les ha preparado para desarrollarse, del grupo de personas reacias a vivir constreñidas en costumbres, tradiciones o hábitos, del grupo de personas que encuentran en el viaje por la vida un sentido para su existencia, del grupo de personas que lo cuestionan todo a la hora de enfrentarse a un mundo que se les presenta a menudo como hostil o vacío, 
del grupo de personas que en ningún momento rehúyen la realidad sino que la enfrentan desde la más recóndita intimidad del yo.

\section{Y guardaba su garra acerada}

Situada en la periferia del poder, Ana Álvarez-Errecalde se ha mantenido cómoda, atenta a los resquicios y las grietas que éste presenta y manteniendo una decidida voluntad de aprovechar cada una de ellas para desafiarlo en todo momento. A tenor de esta afirmación, viene a cuento un verso suelto de Paul Verlaine (1866) en el que, el refinado y desazonante poeta simbolista, deja caer una inquietante sentencia en forma de amenaza, que coincide con esta forma de litigio que Ana mantiene contra el poder hegemónico: $y$ guardaba su garra acerada.

El cambio y la transformación de la realidad son constantes en su vida y en su obra y para vivir y trabajar acorde con ellos se ha nutrido de múltiples valores, tanto individuales como colectivos. Si atendemos al sistema de valores de Schwartz (teoría sobre los valores culturales de las sociedades) y a la dificultad, demostrada, de apropiación de buena parte de ellos en una misma personalidad, deberíamos convenir que Ana presenta una buena combinación del conjunto de los mismos. Valores inclusivos, como por ejemplo la solidaridad, confluyen en la persona y en la obra; asimismo constituye un buen ejemplo de la defensa de minorías o de la equidad social en el apartado de valores universales; pero, sin temor a equivocarnos, podríamos afirmar que es en el apartado de valores emancipados donde Ana se lleva la palma, pues escarba en su medio interno y en su exterior para hacer aflorar su libertad, su audacia, su autonomía y la independencia de criterio y actuación.

Todo ello en aras de encontrar un marco propio que invite a la transgresión, una transgresión que implica el ensayo de alternativas y propuestas conceptualizadas en el entorno de una creatividad que ha convertido en el eje de su obra, en el leitmotiv de su estrategia para deshilachar las sólidas costuras con las que han construido y defendido un régimen hegemónico al que lleva desafiando toda su vida.

Ana Álvarez-Errecalde siempre ha actuado con arreglo a una razón de ser y de hacer que la han llevado a tensar los límites de sus realidades personales hasta desafiar de manera constante los convencionalismos sociales y así exteriorizar su voluntad de vivir manifestándose.

En su quehacer vital, Ana no duda en mostrar su rebeldía y se desmarca de la normativización con afirmaciones como ésta: 
Creo que hacen falta muchas historias de vidas que transgredan el orden establecido para que luego la sociedad valide esas experiencias y logre ofrecer un tejido de contención a esas nuevas necesidades. Veo a las nuevas concepciones familiares como pioneras en el desafío al modelo hegemónico que ampara sólo las necesidades de las familias que sirven con mayor fidelidad al sistema. (comunicación personal, 26 de enero, 2015)

Por lo que respecta a su faceta como artista y a su trayectoria profesional, coincide plenamente con la definición de 'artista' de Guilles Deleuze: «[...] artista es quien habiendo penetrado en la profundidad de la vida y habiendo visto en ella algo demasiado intolerable, surge de ese oscuro abismo con los ojos rojos y, desde esa mirada, traslada a la materia, al pensamiento o al lenguaje sus visiones» (Deleuze, citado por Carro Fernández, 2010: 212).

En sus opiniones, de la misma manera que en sus obras, se encuentran huellas de las convicciones que configuran su personalidad y de las que no duda en hablar de forma directa y descarnada.

\section{Yo he sabido ver la realidad de la sombra}

La relación con el arte ha sido producto de circunstancias personales que han encontrado la colaboración del tiempo, la voluntad de cuestionar el discurso hegemónico y la necesidad de rehuir cualquier tipo de subordinación. Su creatividad fue aflorando de manera espontánea hasta convertirse en un auténtico parámetro para medir e interrogar sus experiencias vitales. Así, Ana Álvarez-Errecalde, a través de la utilización de la cámara como cómplice en su intrusión en la realidad, dotó de contenido a su voluntad de registrar esta realidad, a la vez que la interpelaba, una acción que obedecía, probablemente, a un (sin) sentido cargado de intuición. Como Leopoldo María Panero (1992), en el libro Piedra negra o del temblar, Ana rebusca (in) conscientemente en el envés de su realidad. No ha dudado nunca en confesar: "Sacaba retratos de mi niño y autorretratos. Lo hacía así por falta de otras personas a quienes fotografiar pues estas acciones no tenían ninguna pretensión artística ni me había planteado la posibilidad de mostrar los resultados» (comunicación personal, 26 de abril, 2013). Sin duda, ninguna acción de esta dimensión se lleva a cabo de manera irracional. Quizá el motivo podía inicialmente formar parte del inconsciente, pero el paso del tiempo contribuyó a desentrañar todos los porqués. De hecho, si atendemos a lo que John Berger pone en boca de Susan Sontag probablemente hallemos algunas explicaciones plausibles de la acción de la artista:

Proust en cierto modo interpreta erróneamente qué son las fotografías: no tanto un instrumento como una invención o un sustituto de la memoria. [...] una fotografía no es sólo una imagen (en 
el sentido que lo es una pintura), una interpretación de lo real; también es un vestigio, un rastro directo de lo real, como una huella o una máscara mortuoria [...]. Mediante las fotografías el mundo se transforma en una serie de partículas inconexas e independientes; y la historia, pasada y presente, en un conjunto de anécdotas y faits divers. La cámara atomiza, controla y opaca la realidad. Es una visión del mundo que niega la interrelación, la continuidad, y en cambio confiere a cada momento un carácter misterioso. (Sontag, citada por John Berger, 1980: 56)

Estas afirmaciones de Sontag se adaptan como un guante a la necesidad que sintió la joven Ana al empezar a apretar impulsivamente el disparador de su cámara. Se debería convenir, pues, que en las ideas de la escritora norteamericana se encuentran afinidades electivas con la voluntad inconsciente de Ana. Y, leyendo entre líneas, también se descubren claves para comprender la decisión de la artista de empezar a reflejar su cotidianeidad. «Mediante las fotografías el mundo se transforma [...] », resulta evidente que transformar el mundo o, en su defecto, lo que de éste no aprecia, es una de las actitudes vitales de Ana. Asimismo la posibilidad de atomizar la realidad y darle a cada momento un carácter misterioso, seduce el instinto demiúrgico de la artista y la anima a registrar todo lo que ocurre en su pequeño núcleo habitado. A partir de este momento se suceden, en el álbum fotográfico de Ana, instantáneas que pertenecen a su esfera privada y que no pretenden ser nada más que un registro de su vida.

Avanzar por esta línea argumental le confiere la íntima seguridad de que sus fotografías podrían tener una utilidad casi terapéutica, a la vez que la animan a sentir con mayor ahínco la necesidad de expresarse a través de este medio. Descubrir que sus fotografías pueden contener una narración interior -a diferencia de lo que sucede con los álbumes familiares que le muestran amigos y conocidos-, que lo tratado en ellas va más allá del discurso que busca solazarse en las bondades de la vida doméstica o en el orgullo de la institución familiar y que siguiendo esta veta en lo privado podría llegar a incidir en lo público, incita a Ana a profundizar en la valoración de su propia realidad y a rendir testimonio continuado de la misma.

\section{Sin nombrar lo que ocurre en los márgenes}

En Ana, el acercamiento al arte se ha ido produciendo de manera natural y necesitada a partir de sensaciones muy íntimas y particulares que, pasadas por el cedazo de un fuerte compromiso ético con los colectivos desfavorecidos por el poder, han ido afianzando sus pasos en un mundo que, a través de vorágines de diversa índole, tritura actores sin nin- 
gún tipo de consideración. La experiencia, o mejor dicho la experimentación, han dirigido sus pasos en el ámbito artístico y, así, ha conseguido mantenerse en una línea de expresión personal alejada de las veleidades ligadas a las modas o a los mercados. Atendiendo a lo expresado en el verso de la poeta catalana Esther Zarraluki (1996) que dice sin nombrar lo que ocurre en los márgenes, Ana va configurando el conjunto de su obra con lo esencial de su existencia.

Asimismo, sus particulares teorías sobre el ser madre no han estado determinadas, únicamente, por aquellos grupos que consideraban la maternidad como una imposición social ni como una obligación derivada del simple hecho biológico de ser mujer; al contrario, ella ha sabido sobreponerse a los arquetipos, ha reivindicado la maternidad en libertad como un derecho de las mujeres y ha sabido disfrutar de sus propias maternidades como una experiencia positiva y gozosa. Ella que en lo que hace referencia a su cuerpo y a las actuaciones en torno a la maternidad biológica es de una radicalidad en consonancia con teorías feministas clásicas, no parece estar en el mismo paradigma cuando de la crianza se trata. A tenor de lo que ella misma ha expresado en múltiples ocasiones, e incluso de lo que ha quedado reflejado en estas páginas a partir de diversos contactos, se podría convenir en que su forma de pensar y de actuar coincide con lo que Olaya Fernández Guerrero expresa en su artículo «Encuentros y desencuentros entre el feminismo y la maternidad» (2010). Cuando Fernández Guerrero cita a autoras como Sara Ruddick ${ }^{2}$ o Luisa Muraro ${ }^{3}$, no duda en convocar reflexiones que más allá de considerar la maternidad como una imposición social, tendencia clara de determinados grupos feministas, interpreta esta maternidad como una posibilidad de ejercer libremente los deseos de las féminas en relación a las capacidades de su cuerpo.

Para Ana sus maternidades son categorías discursivas, han sido todo un ejemplo de creatividad productiva y en ningún momento han supuesto una servidumbre ni han devenido ninguna forma de frustración. Esta muestra de creatividad coincidía con lo que sugieren Manuela Mesa, Laura Alonso Cano y Elena Couceiro en su texto Visibles y transgresoras:

La creatividad es un estado mental abierto a la elaboración de alternativas tanto en las maneras de pensar como en las de actuar. Su punto de partida es la realidad misma y se relaciona con ella con la voluntad de transformarla y/o completarla. Se alimenta de preguntas y/o sensaciones poco comunes, elaboradas desde los aledaños del poder, no desde la mirada dominante, tratando de elaborar un recorrido nuevo y alternativo que cuestione la posición

2 «La práctica maternal se basa en el desarrollo de tres actitudes: protección (la madre vela por la seguridad del hijo), nutrición (esfuerzo por cubrir las necesidades básicas, físicas, del hijo) y aprendizaje (la madre trata de inculcar al hijo actitudes y valores que considera positivos)» (Ruddick, citada por Fernández Guerrero, 2010: 428).

3 «...el sentido de ser sólo se puede aprehender plenamente a partir de nuestra relación con la matriz de la vida, y esa relación es la que se establece con la madre en la primera infancia» (Muraro, cit. en Fernández Guerrero, 2010: 430). 
dominante desde su base y fundamento. Construir nuevas miradas, resignificar, renombrar, encontrar alternativas, construir la utopía, poner en valor lo invisibilizado (Mesa, Alonso Cano y Couceiro, 2013: 69).

Las maternidades de Ana han sido una fuente de libertad y han posibilitado su incursión en la rebelión social que siempre ha sentido como un valor propio y, además, han sembrado su camino de autenticidad.

\section{Velada zozobra}

Desde su etapa de formación académica, Ana entró en contacto con el ámbito audiovisual y la videocreación. De su época en New York y de su relación con el cine independiente realizado por minorías como mujeres, latinos, afroamericanos y asiáticos, a Ana le quedó una querencia especial hacia unos grupúsculos que viven la realidad desde perspectivas diferentes a los que ostentan el poder. No le ha resultado nunca difícil, ni raro, afirmar que se ha sentido inmigrante en dos ocasiones y que esta situación la ha llevado a enfrentarse a la vida de diferente manera a los que viven instalados en la comodidad laboral y en un modelo de vida estandarizado. Asimismo, tampoco ha tenido ningún tipo de reparo para expresar su indignación ante la precariedad a la que los gobiernos someten a aquellos que optan por la creación artística. Una velada zozobra interior ha impelido a Ana hacia la creación.

Ana es actualmente madre de una familia numerosa que tuvo unos durísimos inicios con la asunción de la enfermedad de Neuquén, su primer hijo. El conjunto de estas coyunturas, sumado a la necesidad íntima de expresarse, llevaron a Ana a la producción de una serie de instantáneas que se iría prolongando en el tiempo y que acabaría por interactuar con su ámbito familiar más amplio en forma de registro fotográfico. Egología ${ }^{4}$, como se denomina la serie, deriva de un término que le sugirió Rebeca Pardo y que, a pesar de no estar en los diccionarios, reflejaba con exactitud la obra, relacionada con su yo en pasado, en presente y en futuro. El álbum familiar iba creciendo, pues Ana encontraba a cada paso renovados motivos para seguir las huellas que sus seres queridos dejaban en ella $y$, por encima de todo, para seguir registrando las vicisitudes que las mismas personas experimentaban. No había vuelta atrás, se había captado la fugacidad del momento y se había retenido el instante para siempre. La vida, en minúsculas, quedaba registrada una y otra vez como en un sumario.

Evidentemente en esta primerísima fase de su producción la reflexión que acompañaba sus trabajos ofrecía pocos interrogantes. Sin ser meramente descriptiva, estaba muy lejos

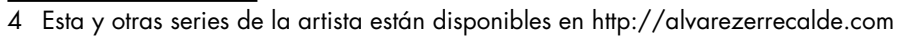


de las rupturas de una familia feliz que proponían autores como Nan Goldin (The ballad of sexual dependency) o como Richard Billingham (Ray's a laugh). En sintonía con trabajos como los citados, Ana se alineaba en el punto de vista de la autorreferencialidad 5 y se podría afirmar que se situaba en el punto de partida adecuado que le llevaría más tarde a elaborar series fundamentadas en la teoría del parentesco $0^{6} y$, por ende, a profundizar en la maternidad como núcleo de trabajo. Egología iba creciendo en número de fotografías y, en torno a los personajes que aparecían en la serie, padres e hijos, se iba hilvanando una maraña de tiempo y espacio con muchos y delicados hilos; la rueca transformada en cámara urdía un tejido capaz de transparentar la realidad. A partir de una experiencia extrema, dado el diagnóstico y el pronóstico de la enfermedad de Neuquén, emergió la voluntad de llevar la maternidad más allá de los límites imaginados y la crianza del hijo proporcionó un impulso vital a la madre para desafiar a un sistema que no era de su agrado. Ella nos dice, una y otra vez, que su «álbum familiar no es 'exitista', no registra celebraciones ni momentos de gloria, sólo registra hechos que me definen e identifican» (comunicación personal, 25 de junio, 2013).

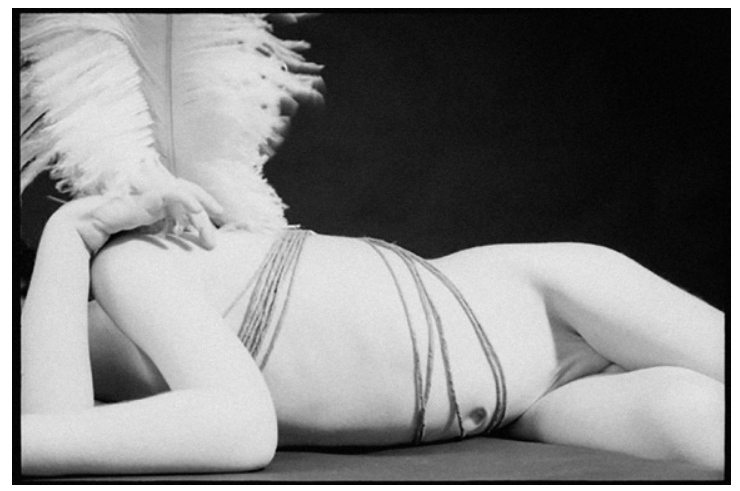

Ana Álvarez-Errecalde. ĺcaro en casa, 2002

\begin{abstract}
5 «En la lógica de la experiencia estética y en su relación con la aparición de lo artístico, la cuestión de la 'reflexividad' nos remite necesariamente al concepto de «autorreferencia». Tal concepto no entraña una noción exclusivamente lógica, ni simplemente tiene un sentido metafórico, sino que se manifiesta como síntoma de una crisis fundamental: el cuestionamiento de los principios racionales de «identidad» y de «no-contradicción». La autorreferencialidad en el «Arte» parece evidenciar la ambivalencia paradójica en la que éste se instala. Nos encontramos ante un problema crítico y crucial que consigue exhibir los límites difusos entre lógica y estética.

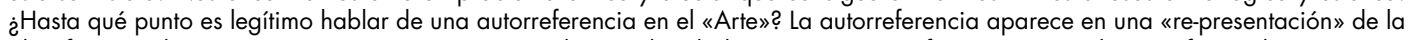
identificación de «sí mismo» por "sí mismo», exigiendo una alteridad que entraña un "efecto retorno» sobre una forma de recurrencia aporética. En tanto «referencia», se muestra como una tendencia a cierto y determinado fin u objeto. Su movimiento necesita del principio de «identidad» y pone en juego necesariamente la noción de «diferencia»» (Álvarez Falcón, 2010: 30).

6 Según Rebeca Pardo: «...sería muy complicado imaginar la fotografía sin el álbum familiar, e incluso podría decirse que sorpresivamente el parentesco en los noventa ha renacido de sus cenizas, un hecho que en artes visuales podría atribuirse al trabajo de feministas y de los estudios de género (representaciones familiares y trabajos de identidad de gays y lesbianas especialmente)» (Pardo, 2013: 56).
\end{abstract}




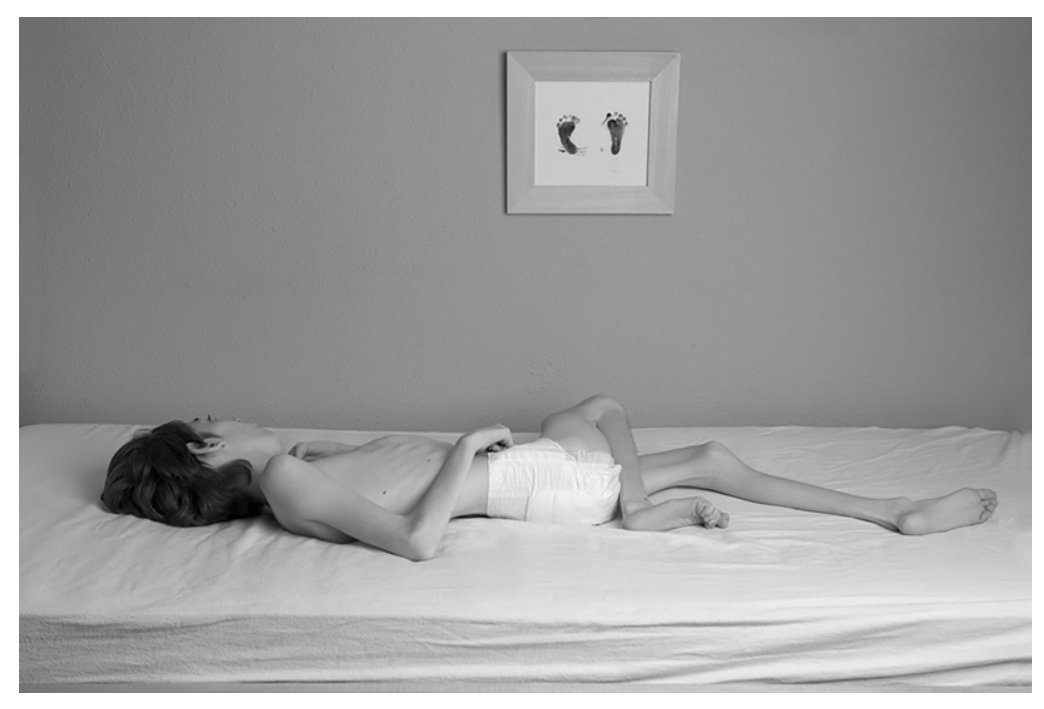

Ana Álvarez-Errecalde. Quinceañero, 2014

La autenticidad de Ana interroga al significado, hurga en la reproducción de la realidad hasta extraer de ella la esencia de lo representado. Sin duda lo consigue en todas y cada una de las imágenes de Egología, pero donde llega a trascender la mera representación es en aquellas series en las que conjuga el cuerpo con elementos considerados abyectos por la sociedad. En muchos de los trabajos de Ana el cuerpo es visitado como la verdadera encarnación, una cualidad estética que dota de fisicidad a la obra. En la serie de Tres gracias sangrantes, dota a su cuerpo de la animalidad a la cual se refiere habitualmente. La artista busca a través de la visión de la sangre, mostrada explícitamente, animar un cuerpo estático pero no exánime, recordar que es un cuerpo vivo y capaz de otorgar vida; clama por dar a conocer la fisiología de la mujer a través de su producción artística. En estas fotografías, y otras similares, da visibilidad al cuerpo de la mujer, una mujer amenazada por la uniformización del sistema, una mujer que desde la infancia hasta la vejez se puede convertir en diana propicia de una sociedad medicalizada, consumista y dominada por la voluntad de los mass media. Las 'gracias' de Ana ejercen, a través de su cuerpo, una dura resistencia al sistema y no dudan en sangrar o en mostrar otros elementos fisiológicos para zafarse del dominio del patriarcado. Menstruación, parto, aborto... son fisiologías teñidas de la sangre que la artista no duda en integrar en su obra, de la misma forma que no duda en fotografiar la herida, la enfermedad o la vejez. 


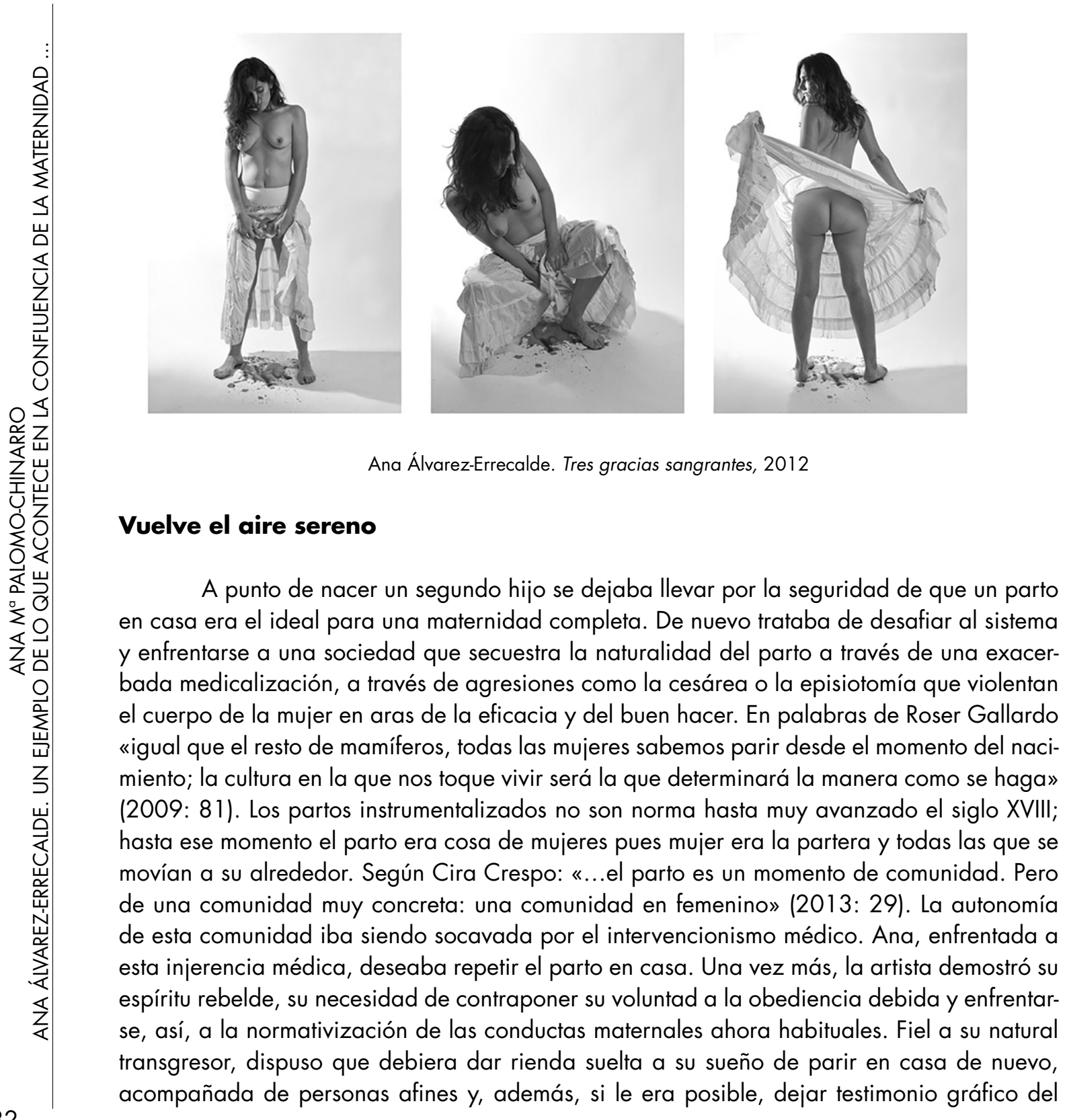


feliz momento. Así pues, preparó una escenografía austera para ilustrar el misterio del parto y desmitificar actitudes que han contribuido a perpetuar roles femeninos que interesaban al patriarcado. En su fuero interno latía la intención de demostrar que también ella, como muchas otras mujeres, había llegado a la mayoría de edad y se la debía tratar como tal. Ana quiso revelar verdades y las verdades deben ser mostradas para que resulten pedagógicas. Pretendía llegar hasta el tuétano de una realidad que mostrara a la mujer como sujeto y que, como sujeto, sangre, grite, ría y llore. Que las emociones trasuden a través de la piel y los gestos, que rezumen los productos biológicos excretados y que transmitan toda la bondad de un momento feliz:

Con estas fotos me interesaba mostrar una maternidad desde mi experiencia, en donde para parir me abro, me transformo, sangro, grito y sonrío. Sonrío porque el dolor me acerca a mi hija, sonrío porque el dolor me demuestra lo fuerte que soy, sonrío porque soy protagonista, sonrío porque soy heroína. Refutando la idea de fragilidad culturalmente aprendida, me interesa mostrarme en control de mi experiencia. Estoy de pie, con la placenta aún dentro de mí, con mi bebé unida a mí por el cordón y hago lo que me da la gana, decido cuando detenerme, hacer la foto y mostrarme (Comunicación personal, 4 de octubre, 2012).

Esta declaración en primera persona devuelve a la mujer el papel principal del momento del parto, el papel que le ha sido usurpado durante muchos años cuando al medicalizarlo se ha apartado el foco de la partera para iluminar a los actores secundarios:

Probablemente todos tenemos en la cabeza -y quizá en algún recóndito lugar de nuestra intimidad- la sensación de rechazo ante ese conjunto de escenas en que una mujer desindividualizada, mera especie- grita o resopla como endemoniada, en una escena que aunque debería protagonizar no deja de ser la escena de otros. La atención queda acaparada por el doctor, la familia expectante o la criatura en su caso (González Marín, 2010: 411).

Ana sólo se imaginó en este instante como la receptora de todas las miradas y la emisora de todas las sensaciones que deseaba transmitir. Su acción nos retrotrae al verso de Sandro Penna (1970): vuelve el aire sereno. La protagonista ejerció a la vez la dirección, dominó el tempo de la realidad y, también, dominó la representación de la misma realidad. Las fotografías que conforman este hermoso y, a la vez, transgresor díptico, son el resultado de una doble función que convocó una maternidad excelsa. Los determinantes biológicos no enmascararon la capacidad reflexiva de la mujer sino que la implementaron. Resulta evidente que con esta representación la artista subvirtió el ideal estético y moral de la maternidad concebida por la sociedad dominante. El pulso al poder social, económico, médico y patriar- 
cal en definitiva, estaba echado: la obra El nacimiento de mi hija se convirtió, por méritos propios, en una maternidad subversiva. La obra cuestiona el parto y traslada la batalla al terreno de la lucha política. El posicionamiento de Ana, más allá del envite a la ética y la moral establecidas, incide en diversos factores que atentan contra el nudo gordiano con el que el patriarcado tiene amordazada a la mujer y a sus acciones. Por una parte, al mostrarse altiva, embadurnada con sus propios flujos biológicos y unida físicamente al bebé, destruye el tabú de la representación de la maternidad en el momento del parto. Por otra parte, flirtea con la voluntad de situar la maternidad como estadio sexual del cuerpo.
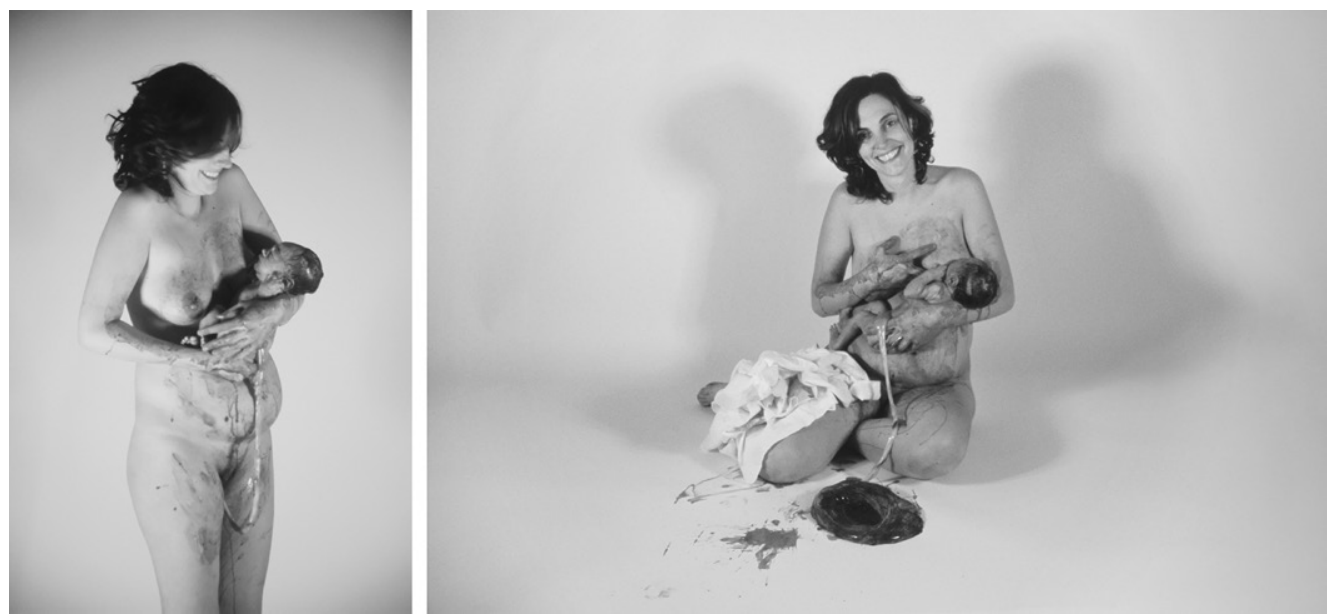

Ana Álvarez-Errecalde. El nacimiento de mi hija, 2005

\section{Acaso habéis visto el tamaño de esta cicatriz, acaso habéis sentido la arcada ante la carne roja que no es sino una muralla entre lo moral y lo inmoral, entre mi estómago y mis sentimientos, entre tú y...}

Situada ya en un ámbito artístico destacado, después de diversas apariciones en galerías y otros espacios expositivos, Ana sintió como un valor personal los partos en casa y se posicionó contra cualquier tipo de medicalización de la maternidad. No es de extrañar, pues, que cuando la asociación El Parto es Nuestro le propuso participar en una publicación que pretendía «reparar» las heridas dejadas por las cesáreas en el cuerpo de las madres 
sometidas a estas intervenciones quirúrgicas, aceptara casi de inmediato ${ }^{7}$. En la serie se recogieron una treintena de fotografías que tenían como elemento central la cicatriz provocada por una intervención quirúrgica; en algún momento de la serie aparece un irónico subtítulo con la frase el (nuevo) origen del mundo, en clara alusión al famoso cuadro de Courbet, dada la cantidad de cesáreas que se dan en los partos instrumentados. En todas las fotografías la cicatriz resulta una huella indeleble que queda marcada en la piel de la misma forma que ha quedado grabada en la historia de vida de la mujer que la muestra; en todas ellas oímos resonar la frase inquisitiva de Luna Miguel, de su libro Los estómagos, que da título a este apartado: Acaso habéis visto el tamaño de esta cicatriz...

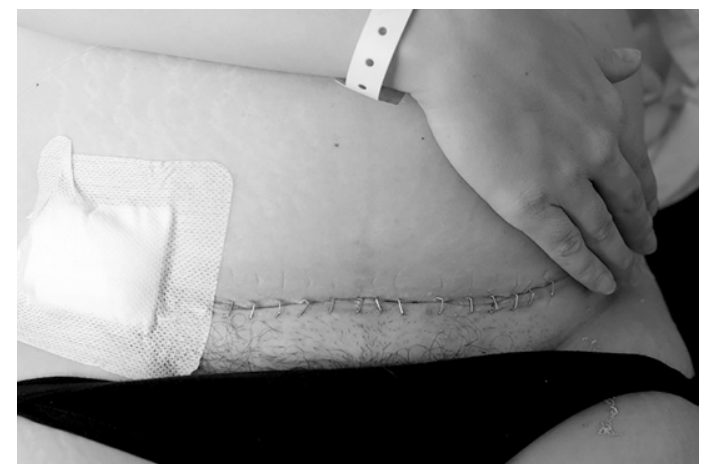

Ana Álvarez-Errecalde. De la serie Cesárea, más allá de la herida, 2009

\section{Sin más horizonte que otros ojos frente a frente}

La serie Las 4 estaciones, realizada en 2014, ofrece cuatro autorretratos de la propia Ana que tienen un solo ente común: el resultado de la gestación, el fruto de la concepción.

7 «En España se hacen cada año más de 100.000 cesáreas. Aproximadamente la mitad son innecesarias. Cien mil madres heridas y cien mil maneras de vivir la herida. Con gozo o con dolor, con alivio o con inmensa rabia, siempre queda una marca. «Podrás seguir llevando bikini es en ocasiones lo que el cirujano dice a la madre en el quirófano. Promesa de una cicatriz invisible y deseo de que la intervención no deje huella en el cuerpo ni en el alma. Negación una vez más del dolor de muchas madres: «pero tú de qué te quejas si tienes un bebé sanos. Pero grande o pequeña la cicatriz en el vientre será de por vida recordatorio del sacrificio al que nos sometimos por el bien de nuestros hijos.

Cuidar la herida, tocar la cicatriz, mostrarla, aceptarla e integrarla suele ser difícil. Las mujeres tenemos poca costumbre de mostrar las cicatrices y la mayoría de las madres cesareadas sólo han visto una cicatriz: la suya propia. A veces ni siquiera eso: hay mujeres que no se sienten capaces de mirar su propia herida.

La cirugía estética nos ofrece borrar las marcas, no sólo de la cesárea sino también las huellas que la maternidad deja en nuestros cuerpos. Eliminar las cicatrices, igual que escondemos la tripa, las curvas o el pecho caído. Como si necesitáramos un solo modelo de cuerpo para un pensamiento único, se nos ofrece más cirugía innecesaria, más ocultación de la corporalidad de las madres» (Olza, 2010: s.p.). 
Otra vez la maternidad en el epicentro de su vida. Ella, que ha situado el cuerpo, el embarazo, el parto y la crianza en un imaginario en el que faltaba como elemento iconográfico -pues la perspectiva masculina heterosexual occidental y patriarcal había decidido que debía formar parte de lo privado, de lo doméstico, de lo oculto a los ojos del público-, decide acudir al imaginario popular para rescatar figuras religiosas, paisajísticas, literarias o provenientes del cómic o del pulp y convertirlas en protagonistas y/o cómplices de sus trabajos. Virginidades, licantropías y súper-heroínas ocupan el eje vertebrador de una serie que destila conceptualidad y composición más allá de la autenticidad con la que siempre había tratado el cuerpo de la mujer, sus partes y sus ciclos.

El autorretrato sitúa a la madre en un centro que siempre comparte con el fruto de su embarazo. Un verso de Cernuda (1933) define a la perfección el encadenado de la serie: sin más horizonte que otros ojos frente a frente. Sentada, de pie, de perfil o de espaldas, la madre ejerce su
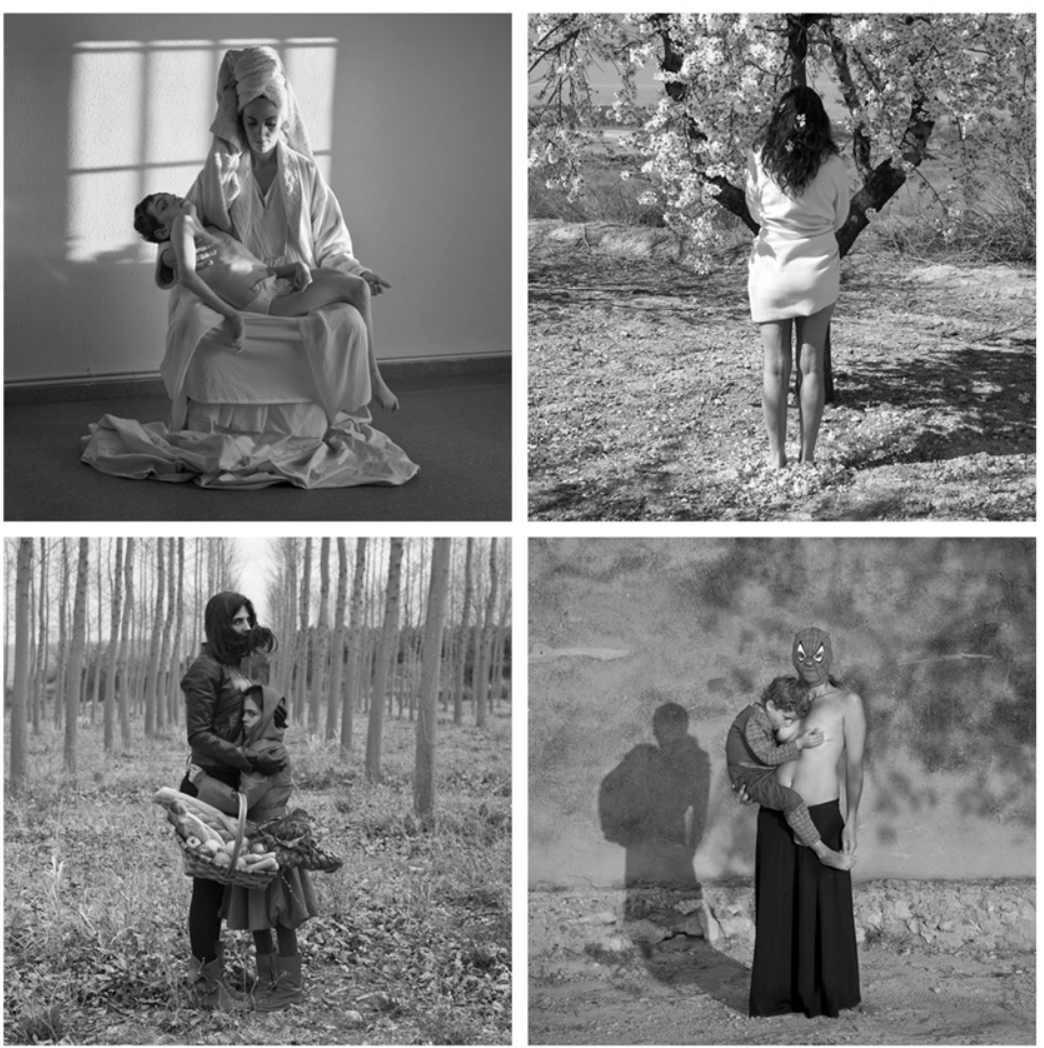

Ana Álvarez-Errecalde. Anunciación, 2014, Ana Álvarez-Errecalde. Asentir, 
influencia ambivalente sobre el hijo que demuestra su vulnerabilidad, inocencia o temor. El concepto de ambivalencia al que nos referimos no queda, en el caso de Ana, limitado a lo que en algunos textos feministas, $y$ en el otro extremo en algunos panfletos reaccionarios, queda definido como buena madre/mala madre, sino que tiene que ver con las influencias positivas y deseadas o las negativas e inevitables que toda madre puede ejercer sobre sus vástagos. En esta serie llega el turno del autorretrato con el tercer hijo de Ana; con Simbiosis, título de la foto, también llega el escándalo. La revista norteamericana Hip Mama, que pasa por ser una publicación alternativa para madres y padres, la censuró. Según parece, la visión del pezón en la foto hizo que la distribuidora se negara a que fuera portada de la revista en un claro ejemplo de hipocresía de mercado.

En este trabajo, quizá como en ningún otro, se nos muestra extremadamente madura, segura de que el carácter que se ha ido forjando como mujer y como madre la sitúa en un puesto preeminente; convencida de que, desde la situación adquirida, puede servir de ejemplo a otras muchas mujeres. Si con el díptico El nacimiento de mi hija encontró la manera de comunicar que otras mujeres podían hacer lo mismo que ella, pariendo en casa de manera tranquila y segura, en Simbiosis parece querer demostrar que una madre, unida de forma simbiótica a un hijo -o a más hijos- es autónoma y sobre todo autosuficiente. Acaba por decirnos que cualquier mujer puede situarse en la misma posición que ella nos manifiesta, que cualquier mujer puede, como la de la imagen, enfrentarse al mundo por muy hostil que este le resulte.

\section{A modo de conclusión}

Las vivencias, experiencias y obras de Ana Álvarez-Errecalde demuestran que estamos ante una mujer y una artista singular que, desde siempre, ha huido de obligaciones, obediencias, normativizaciones y determinantes de cualquier tipo. La evolución de Ana, ha seguido un rumbo fijo, sin derivas importantes a pesar de que en este camino no todo ha resultado fácil. Con un carácter forjado en la ejemplaridad de unos padres, que la apoyaron y que hicieron del respeto y de la confianza paradigma de su relación, y en la propia voluntad de ser fiel a sus más íntimas convicciones, la personalidad de la mujer y de la artista se ha desarrollado con arreglo a parámetros muy firmes y a un equilibrio armónico en todos los aspectos.

Conviene aclarar que la vida y la obra de Ana se fundamentan en valores sólidos. Se trata de unos valores que hasta cierto punto se podrían considerar tradicionales, que ella tensa siempre hasta el límite y que la enfrentan continuamente al modelo hegemónico de comportamiento social. Si en algún momento se han podido interpretar sus valores como 
caducos y se han creído basados en modelos de sociedad antiguos, ella misma lo desmiente con afirmaciones, que de viva voz o través de sus fotografías, deja sobre la mesa de debate.

La artista no ha dudado en imbricar su vida en su obra hasta contribuir, con algunos de sus trabajos, a reconfigurar un imaginario que estaba huérfano de algunos ciclos de esta maternidad y que ella no ha dudado en abordar y representar de manera personal. Desde la autenticidad de sus propuestas, la maternidad en sus fases de embarazo, parto, lactancia y crianza, formas alejadas de la iconografía convencional, consiguen sacarse el velo que las cubría y emerger entre las tinieblas hasta ser representadas con total naturalidad. Ana Álvarez-Errecalde también ha utilizado su cuerpo en diversas ocasiones, las huellas dejadas por la maternidad en su cuerpo y en el de otras mujeres, para denunciar la cosificación que se pretende desde el poder del patriarcado hegemónico y ensalzar, así, a la mujer como sujeto del ámbito público, alejándola de la objetualización, de la domesticación y de la reclusión en lo privado.

Cabe recordar que se ha definido a sí misma como «...una loba de pelo gris que sale a merodear sin su manada, pero que tan pronto como quiere se une a ella, disfruta fuera porque sabe que tiene madriguera. Necesita un espacio íntimo. Aúlla para mantenerse en contacto» (Comunicación personal, 26 de abril, 2013). En estas afirmaciones descubrimos atributos de la persona luchadora, de la artista transgresora, de la mujer que muestra su instinto, del mamífero que no duda en presentarse tal como es y de hacerlo desde la animalidad más subversiva. Atributos que de ninguna manera buscan soslayar aspectos más humanos, que sin duda atesora, como la sensibilidad, la afectividad, la responsabilidad, la entrega y el miedo. La personalidad de Ana, igual que su obra, descansa en una revisión constante del conjunto de aquellos valores y de estos atributos.

Si mujer, madre y artista ha sido, desde antaño, una ecuación cargada de variables inhóspitas que con frecuencia ha dado al traste con trayectorias tanto personales como profesionales, no ha sido éste el caso de Ana Álvarez-Errecalde que ha sabido convertir la suma de estas realidades en una propuesta de acción personal y profesional que le ha procurado una importante proyección.

\section{Referencias y bibliografía}

Álvarez Falcón, Luis (2010): «La 〈autorreferencialidad〉 de la experiencia estética». En Fedro. Revista de estética y teoría de las artes, núm. 9, pp. 30-42. 
Carro Fernández, Susana (2010): Mujeres de ojos rojos. Del arte feminista al arte femenino. Gijón: Trea.

Cernuda, Luis (1998) [1932-1933]: 34 poemas. Madrid: Grijalbo Mondadori.

CRESPO, Cira (2013): Maternalias. De la historia de la maternidad. Tenerife: OB STARE.

Fernández Guerrero, Olaya (2010): «Encuentros y desencuentros entre el feminismo y la maternidad». En Franco RuBio, Gloria A. (Ed.), Debates sobre la maternidad desde una perspectiva histórica (siglos XVI-XX) (pp. 425-438). Barcelona: Icaria Editorial.

Gallardo FerRer, Roser (2009): «Parir en primera persona. El poder de las mujeres en el parto». En Mètode, núm. 62, pp. 81-87.

González Marín, Carmen (2010): «วMamá drag king?» En Franco Rubio, Gloria A. (Ed.), Debates sobre la maternidad desde una perspectiva histórica (siglos XVI-XX). Barcelona: Icaria Editorial, pp. 411 1-424.

GutiérRez-Rubí, Antoni (2009): «Poder en femenino». En Antoni Gutiérrez-Rubí. Artículos y reflexiones [en línea]. Disponible en: http://www.gutierrez-rubi.es/2009/01/21/ poder-en-femenino [Fecha de consulta: 4 de octubre de 2015].

Lagarde, Marcela (2000): Claves feministas para liderazgos entrañables. Managua: Puntos de encuentro.

Mesa, Manuela, Laura Alonso Cano y Elena Couceiro Visibles y transgresoras. Narrativas y propuestas visuales para la paz y la igualdad. Madrid: Fundación Cultura de Paz/ CEIPAZ.

Miguel, Luna (2015): Los estómagos. Córdoba: La Bella Varsovia.

OlzA, Ibone (2010): «Prólogo de presentación». En Cesárea. Más allá de la herida. Ana Álvarez-Errecalde [catálogo de exposición]. Tenerife: OB STARE.

PANeRO, Leopoldo María (1992): Piedra negra o del temblar. Madrid: Libertarias/Prodhufi.

PARDO SAINZ, Rebeca (2013): «La familia en el arte y la antropología del parentesco». En Revista Sans Soleil - Estudios de la Imagen, vol. 5, núm. 1, pp. 48-63.

PenNA, Sandro (1970): Cruz y delicia. Estrañezas. Barcelona: Lumen, 2007.

VerLAINE, Paul (1866-1888): Poesías completas. Barcelona: RBA, 2001.

ZARRALUKI, Esther (1996): Cobalto. Barcelona: DVD ediciones.

Recibido el 20 de enero de 2016 Aceptado el 28 de febrero de 2016 BIBLID [1 139-1219 (2016) 21: 23-39] 